\title{
DEMOKRATIJOS „IŠDAVIMO“
}

PAMOKA LIETUVOS VALSTIEČIŲ

LIAUDININKŲ PARTIJAI

\author{
Mindaugas TAMOŠAitis
}

Vilniaus pedagoginio universiteto Istorijos fakultetas

Vilnius Pedagogical University Faculty of History

T. Ševčenkos 31, LT-03111 Vilnius

El.paštas:lietistkat@vpu.lt,m_tamosaitis@yahoo.com

\section{Santrauka}

Straipsnyje prisimenamas $1926 \mathrm{~m}$. gruodžio $17 \mathrm{~d}$. Lietuvoje ivykęs valstybès perversmas, kuomet žlugo demokratinè parlamentinè santvarka ir šalyje pradejo formuotis antidemokratinis valdymas. Perversmo metu demokratija, tikraja to žodžio prasme, buvo išduota. Dèl to, kas ivyko, išskirtine atsakomybe tenka valstiečiu liaudininku vadovybei, kuri, turèdama savo rankose valdžia, lemiamu momentu demokratijos ne tik kad negyne, bet netgi perversmininkams padejo legalizuoti ju antidemokratinius veiksmus. Toks liaudininku vadovybès poelgis turëjo skaudžiu pasekmiu tolimesnei šalies ir partijos raidai. Daroma išvada, kad 1926 m. gruodžio 17 d. liaudininku vadu veiksmai - pamoka, kaip nereikia elgtis iškilus pavojui demokratinei santvarkai.

Tyrimas parengtas remiantis archyvine medžiaga, to meto periodine spauda, amžininku atsiminimais, istoriku tyrimais.

Reikšminiai žodžiai: Lietuvos valstiečiu liaudininkų sajunga; valstybės perversmas; demokratija; ,kartų konfliktas“; jaunieji valstiečiai liaudininkai; Lietuvos jaunimo sajunga; autoritarinis valdymas; Valstybès saugumo departamentas. 


\section{Ivadas}

„, Kiekvienas demokratas turi žinoti, kad demokratija visam pasauly ir atskiroj valstybejj atsirado ne pati per save, bet dèka atkakliai ištvermingai geriausiu piliečiu kovai. Atmindamas tai, demokratas drasiai turi kovoti už tolimesni tobulinima ir gilinima demokratijos idejju ir visomis savo išgalemis priešintis pasikèsinimams ant demokratijos principu ir jos istaigu, nepaisydamas to, iš kur eina pavojus demokratijai ir kas kesinasi ant jos idejju“1.

1926 m. gruodžio 17 d. „,be šūvio“ ỉvykęs valstybès perversmas sudavè lemiamą smūgi parlamentinei demokratinei santvarkai Lietuvoje. Vyriausybė visiškai nekreipė dèmesio į prieš tai jau kurị laiką sklandžiusius gandus apie planuojamą pasikèsinimą i demokratiškai išrinktą teisètą valdžią, nesièmė jokių priemonių galimam pavojui likviduoti. Perversmininkai be didesnio vargo suèmė Respublikos Prezidentą Kazi Griniu, Vyriausybès narius, užèmè svarbiausius valdžios postus ir tapo politiniais padèties šeimininkais. Tai padaryta ,be didelio triukšmo“, , ,ivykus perversmui, konstitucinè santvarka iš karto savaime žlugo" ${ }^{2}$, ją ėmè keisti antidemokratinis valdymas, kurio priekyje atsistojo tautininkų lyderis Antanas Smetona.

Dèl to, kas ịvyko, išskirtinè atsakomybė tenka Lietuvos valstiečiu liaudininkų sajungos (toliau - LVLS) vadovybei, jos lyderiams - tuometiniam Prezidentui K. Griniui ir Ministrui Pirmininkui Mykolui Sleževičiui. Liaudininkų vadai, nuo Vinco Kudirkos laikų visuomenèje pagarsèję kaip didieji demokratai, $1926 \mathrm{~m}$. pabaigoje palūžo. Valdžia neparodè jokių pastangu̧, kad apsaugotų „Seimą ir pačią vyriausybę nuo sąmokslininkų “3. Maža to, LVLS vadovybè, laikydamasi labai pasyvios taktikos, prisidèjo prie gruodžio perversmo padarinių legalizavimo ${ }^{4}$, ko niekaip negalëjo pateisinti buvę koalicijos partneriai socialdemokratai ${ }^{5}$. Anot Mykolo Romerio, šiuo atžvilgiu socialdemokratai, kurie legalizavimo „vaidinimui“ nepritarè, buvo nuoseklesni ir

1 Toliušis, Z. Demokratija ir jos priešai, arba Demokrato katekizmas. Kaunas, 1926, p. 36.

${ }^{2}$ Rèmeris, M. Lietuvos konstitucinès teisès paskaitos. Vilnius, 1990, p. 212.

3 Skipitis, R. Nepriklausoma Lietuvq statant: atsiminimai. Chicago, 1961, p. 410.

${ }^{4}$ Stakeliūnaité, D. 1926 m. gruodžio 17 d. perversmo padarinių legalizavimas: Lietuvos valstiečiu liaudininkų sajungos vadovybès pozicija. Istorija. 1999, t. 41, p. 34-39.

1926 m. gruodžio 30 d. Seimo posèdyje LSDP frakcijos narè Liuda Purénienè, kreipdamasi į Ministrą Pirmininką Augustiną Voldemarą, pareiškè: ,Jeigu jūs jau valdžią esate paėmę, jeigu liaudininkai iš po jūsų kojų pašalino visas kliūtis, kad jūs greičiau atsistotumèt valdžios priešaky, kada per vieną dieną ir Ministerijų Kabinetas atsisakė ir Prezidentas atsisakè ir pagaliau dr. J. Staugaitis buvo priverstas atvažiuoti čia ị Seimą ir atidaryti Seimo posèdị, kad duotų jums galimumo išrinkti naują Prezidentą, tai kam po to visos tos represijos?“ (Trečiojo Seimo stenogramos. III sesija, 66 posėdis, 1926 m. gruodžio 30 d. Kaunas, 1927, p. 27). 
pasirodè labiau subrendę, ,politiškam menui“ “6 . Anot istorikès Danutės Stakeliūnaitès, „sutikdami perversmini vyriausybès [sudèties] pakeitimą legalizuoti, liaudininkai tuo pačiu ši perversmo padarini sankcionavo, taip sakant, patys savo rankas sutepė perversmu, pritare sau suduotam smūgiui, patys, taip sakant save išplake்“" . Užuot pasiaiškinę dèl ,tokių“ savo veiksmų partiečiams ir visuomenei, liaudininkų vadai pirmosiomis savaitėmis po perversmo išliko pasyvūs ir savo „,besąlyginès kapituliacijos" motyvų nemėgino paaiškinti ${ }^{8}$. Tokia valstiečių liaudininkų vadų taktika sulaukė daug kritikos, gerokai sumažino jų autoritetą visuomenèje ir pačioje partijoje. Tai akivaizdžiai išryškèjo ketvirtajame dešimtmetyje, kai prasidèjo senujų partijos vadų (,seniü“) ir jaunosios kartos - jaunujų valstiečių liaudininkų konfliktas "10. Bene centrine nesutarimų šerdimi buvo gruodžio $17 \mathrm{~d}$. ịvykiai ir LVLS vadovybės veiksmai. Demokratijos negynimas ir savo skelbiamų principų,,išdavimas“ 1926 m. gruodžio 17 d. senają valstiečių liaudininkų vadovybę tarsi šešèlis persekiojo per visą ketvirtaji dešimtmeti. Iškilusi jaunoji liaudininkų karta to nenorejo atleisti, o partijos silpnejjimas, nepajėgumas plètoti aktyvesnę veiklą jaunają kartą stūmė nuo „senių“ ir didino takoskyrą tarp abiejų stovyklų, kuri dar labiau išryškejjo okupacijos išvakarèse.

Istoriografijoje daug dèmesio skiriama gruodžio $17 \mathrm{~d}$. ịvykiams, todèl neišvengiamai aptariama liaudininkų vadovybès pozicija lemtinguoju momentu ${ }^{11}$. Nepaisant to, gruodžio $17 \mathrm{~d}$. LVLS vadovybės veiksmu itaka ir pamokos pačiai partijai iš esmès nèra aptartos. Užtektu paminèti Kazio Škirpos atsiminimus apie M. Sleževičių ${ }^{12}$. Išimtị sudare istorikès D. Stakeliūnaitès tyrimai. Tyrẻja gana išsamiai aptarè pasyvius liaudininkų vadų veiksmus perversmo metu ir iš karto po jo $(1926 \mathrm{~m}$. pabaigoje-1927 m. pradžioje) $)^{13}$, mėgino juos paaiškinti. Šia publikacija tarsi norima pratęsti minètos istorikès tyrimus: a) išsamiau aptarti valstiečių liaudininkų vadovybés

${ }^{6}$ Rèmeris, M. Lietuvos konstitucinès teisès paskaitos. Vilnius, 1990, p. 212.

${ }^{7}$ Stakeliūnaitè, D. 1926 m. gruodžio 17 d. perversmo padarinių legalizavimas: Lietuvos valstiečių liaudininkų sajungos vadovybės pozicija. Istorija. 1999, t. 41, p. 34-39.

${ }^{8}$ Stakeliūnaitè, D. Valstiečiai liaudininkai Lietuvos Respublikos vidaus politikoje $1918 \mathrm{~m}$. pabaigoje-1926 m.: parlamentinè veikla: daktaro disertacija. Kaunas, 2000. Lietuvos nacionalinés Martyno Mažvydo bibliotekos Rankraščiu skyrius (toliau - LNMMB RS). F. 132-1469.

9 Jauniesiems valstiečiams liaudininkams atstovavo Lietuvos jaunimo sajunga (LJS) (kitaip dar vadinami jaunimiečiai) ir jaunieji studentai varpininkai, priklausantys Vytauto Didžiojo universiteto (VDU) studentu „Varpo“ draugijai, taip pat jau baigę studijas ir anksčiau jai priklausę studentai (Rūkas, A. Studentai varpininkai 1923-1938. Varpininkų kelias: studentų varpininkų XV metų sukakčiai paminèti jubiliejinis leidinys. Kaunas, 1939, p. 197-214).

${ }^{10}$ Išsamiau žr:: Tamošaitis, M. Justas Paleckis ir jaunieji valstiečiai liaudininkai Lietuvai atgaunant Vilniaus kraštą (1939 m. ruduo). Vilniaus istorijos metraštis. Vilnius, 2006, t. 1.

${ }^{11}$ Butkus, Z. Dr. Kazys Grinius: Lietuvos Respublikos Ministrai Pirmininkai 1918-1940. Vilnius, 1997, p. 252-253; Ilgūnas, G. Kazys Grinius. Vilnius, 2000.

${ }_{12}$ Škirpa, K. Mykolas Sleževičius. Chicago, 1954.

${ }^{13}$ Stakeliūnaitė, D. Valstiečiai liaudininkai Lietuvos Respublikos vidaus politikoje 1918 m. pabaigoje-1926 m.: parlamentinè veikla: daktaro disertacija. Kaunas, 2000. LNMMB RS. F. 132-1469. 
veiksmų 1926 m. gruodžio 17 d. ịtaką Valstiečių liaudininkų partijai trečiojo dešimtmečio pabaigoje-ketvirtajame dešimtmetyje; 2) pamėginti atsakyti i klausimą kodèl 1940 m. birželi, Lietuvos okupacijos pradžioje, jaunoji liaudininkų karta palankiai sutiko sovietu kariuomenę ${ }^{14}$. Iš karto reikia pasakyti, kad dèl ribotos šio straipsnio apimties tik fragmentiškai užsimenama apie ketvirtajame dešimtmetyje liaudininkų partiją ištikusius sukrètimus, nes tai pareikalautų atskiros publikacijos.

Straipsnis parengtas remiantis archyvuose, rankraštynuose saugoma istorine medžiaga, to meto spauda, ivvykių atsiminimais, istorikų darbais. Daugelis šaltinių i mokslinę ,apyvartą" itraukiami pirmą kartą.

\section{Liaudininkų vadovybės ir partijos narių santykiai trečiojo dešimtmečio pabaigoje}

Po to, kad 1926 m. gruodžio 17 d. LVLS ir Lietuvos socialdemokratu partija (toliau - LSDP) priverstinai pasitraukè i opoziciją, su tuo nenorejo susitaikyti aktyvesni šių partijų veikẻjai. Jau 1927 m. pradžioje grupė socialdemokratų ir atskiri valstiečiai liaudininkai siekè ịvykdyti valstybės perversmą ir sugrąžinti demokratinị valdymą šalyje (šiems veiksmams vadovavo socialdemokratas, buvęs keturių demokratinių Seimųnarys Jeronimas Plečkaitis, jo šalininkai vadinami ,plečkaitininkais“. Tuo pačiu metu aktyviai veikè valstietis liaudininkas, buvęs III Seimo narys Juozas Pajaujis ir jo šalininkai ${ }^{15}$ ). Jèga nuversti A. Smetonos nepavyko, o asmenys, mėginę tai padaryti, buvo suimti ir nubausti ${ }^{16}$. Aktyvūs socialdemokratų ir kai kurių liaudininkų narių veiksmai sukèle dar didesnes Lietuvos valdžios represijas. Keletas valstiečių liaudininkų ir LSDP narių kuriam laikui buvo uždaryti i Varnių koncentracijos stovyklą ${ }^{17}$. Ivairiomis priemonèmis pradèta slopinti opozicinių partijų veiklą $(1927 \mathrm{~m}$. balandį buvo paleistas III Seimas), kiek vèliau tautininkai iš valdžios išstūmė Krikščionių demokratų partiją. Lietuvoje pradejo kurtis vienvaldis A. Smetonos autoritarinis valdymas.

${ }^{14}$ Čia turima omenyje ne istoriografijoje jau gana didelio dèmesio sulaukę jaunujų valstiečių liaudininkų veiksmai okupacijos išvakarès ir okupacijos pradžioje (išsamiau žr.: Tamošaitis, M. Kairiosios lietuvių inteligentijos veiksmai Lietuvos okupacijos išvakarèse ir pirmomis okupacijos dienomis. Genocidas ir rezistencija. 2006, Nr. 1, p. 62-84), o patys motyvai, turejję lemiamos įtakos tokiems jaunujų liaudininkų poelgiams.

15 Reikia pažymèti, kad po gruodžio $17 \mathrm{~d}$. valstybès perversmo jaunosios kartos atstovas J. Pajaujis tapo savotišku liaudininkų partijos lyderiu. 1926 m. gruodžio pabaigoje ir 1927 m. pradžioje Seime jis atvirai smerkẻ perversmininkus, pabrèžè demokratines vertybes. Jeigu tų metų balandžio 4 d. nebūtų areštuotas, nežinia, kaip būtų susiklosčiusi jo politinė karjera.

${ }^{16}$ Valstybės saugumo departamento direktorius A. Povilaitis: Sukilimai Lietuvoje nuo nepriklausomybès atgavimo iki šių (1939) metų sausio mèn. 1 dienos. Gairès. 1996, Nr. 4, p. 28-29.

${ }_{17}$ Truska, L. Antanas Smetona ir jo laikai. Vilnius, 1996, p. 176-180. 
Nepaisydama atskirų savo partijos narių drastiškų veiksmų ir mėginimo prievarta rekonstruoti demokratinę santvarką, LVLS vadovybé išliko pasyvi. Nenoriai prisimindama savo veiksmus per gruodžio $17 \mathrm{~d}$. ivvykius, liaudininkų vadovybẻ juos aiškino tuo, kad valdžios nesipriešinimas perversmininkams padèjo išvengti pilietinio karo ar didelès suirutès šalyje, kuriais galèjo pasinaudoti užsienio valstybès. 1926 m. gruodžio 21 d. liaudininkų dienraštis „Lietuvos žinios“ K. Griniaus ir M. Sleževičiaus atsistatydinimą prilygino didžiajai aukai: „Pasiaukojimas aukščiausiems krašto reikalams be abejonès bus tinkamai suprastas ir ịvertintas demokratinės Lietuvos visuomenės“18. Greta išspausdintame kitame straipsnyje liaudininkų vadams buvo dẻkojama už veiksmus perversmo metu, visuomenè kviečiama ,daugiau kaip kada nors palaikyti tvarką ir ramybę“: „Ne ta yra tikroji motina, kuri sutinka, kad kūdikis būtų pusiau perskrostas, bet ta, kuri sutinka kūdikị verčiau kitai perleisti, bet tik jis gyvas liktų. Taip reikia įvertinti Griniaus atsistatydinimą ir skubotą naujos vyriausybès patvirtinimąa". Tiesa, patị valstybès perversmą liaudininkai pasmerkè ${ }^{19} .1927 \mathrm{~m}$. pradžioje panašiai samprotavo M. Sleževičius, šiuos įvykius palikdamas vertinti istorijai ${ }^{20}$. Iš to matyti, kad liaudininkų vadai skaudžiai išgyveno dèl nesenų įvykių. Tą patvirtina po Antrojo pasaulinio karo paskelbti K. Griniaus atsiminimai ${ }^{21}$.

Reikia sutikti su istorike D. Stakeliūnaite, kad LVLS Centro komiteto (toliau - CK) ir visos partijos autoritetą perversmo metu gelbèti reikejjo. Ji turèjo omenyje ne ginkluotą pasipriešinima, bet viešą tvirtos griežtos pozicijos pareiškimą. Tai nebuvo padaryta. Tuo metu M. Sleževičiaus politinio nuosaikumo linija atrodè kaip savo principų išdavystè ${ }^{22}$. Liaudininkų vadovybè, užuot reiškusi protesta, nuo pat pradžių naiviai pasitikèjo perversmininkais ir mané, kad greitu laiku Lietuvoje bus atkurta demokratinė konstitucinè tvarka. 1927 m. sausio 5 d. LVLS CK sekretoriato išleistame atsišaukime, skirtame valstybės perversmui, vadovybè pirmą kartą (ne spaudai) partijos nariams išsamiau pabande paaiškinti savo veiksmus perversmo metu ir aptare partijos padètị po perversmo. Partijos vadovai prisipažino, kad gruodžio 17 d. îvykiai Kaune ,turbūt ne vieną nustebino“, ivvertino pasunkejjusias partijos veiklos sąlygas (,visai netikètai vèl

${ }_{18}$ Perversmas ir kas toliau (vedamasis). Lietuvos žinios. 1926, gruodžio 21, p. 1.

${ }^{19}$ Respublikos išlikimas - aukščiausias įstatymas (vedamasis). Lietuvos žinios. 1926, gruodžio 21, p. 1.

${ }^{20}$ Laiško pabaigoje, prieš tai aprašęs liaudininkų vadovybès poelgius perversmo metu, M. Sleževičius rašè: „Aprašiau, kaip galèjau, Tamsta supratai, kad ir dabar nelengva man apie tai kalbėti. Aš nesprendžiau ar gerai padariau ar ne?" (M. Sleževičiaus laiškas JAV lietuvių veikejjui A. B. Strimaičiui, rašytas 1927 m. vasario 19 d. ị Niujorką. Lietuvos istorijos straipsniu ir dokumentu rinkinys. Vilnius, 1999, p. 563).

${ }^{21}$ Grinius, K. Apie 1926 metų gruodžio 17-os dienos perversmą. Sudarė A. Eidintas. Kazys Grinius. Vilnius, 1993, p. 147-191 (atsiminimai paskelbti JAV spaudoje 1954 m. - autoriaus pastaba).

${ }^{22}$ Stakeliūnaitè, D. 1926 m. gruodžio 17 d. perversmo padarinių legalizavimas: Lietuvos valstiečių liaudininkų sajungos vadovybès pozicija. Istorija. 1999, t. 41, p. 34-39. 
teko grižti į tuos laikus, kuriuos buvome pragyvenę ir palikę istorijai minèti“(23) ir ragino nepasiduoti pesimizmui: „Ši kartą mes visai privačiai Jums rašome dèl organizacijos. Gruodžio 17 d. įvykiai, žinoma, turejjo atsiliepti į žmonių ūpą ir visos organizacijos darbus. Gal būt daugelis narių buvo pagauti nusivylimo, kiti pykčio apimti, kad prie tokių ivvykių daleista, treti, gal būt, nebuvo patenkinti, kam Centro Komitetas padarè tiek daug nuolaidų sukilèliams ir padèjo be kovų eiti prie normalaus gyvenimo. Gali rastis dar ir daug kitų nuomonių. Vienok visa čia neišgvildensime ir verčiau, draugai, visus kaltinimus ir nepasitenkinimus palikime patogesniam laikui arba būsiantiems apskričių suvažiavimams svarstyti ir Centro Tarybos posėdžiui teisti. O mes tuo tarpu stiprinsime savo jègas tai kovai, kuri mūs laukia. Todèl dabar vieno iš jų laukiame, kad nenusimintumète, nes organizacija dèl to nèra dar žuvus ar viskas pralaimèta“24. Toliau partijos vadovybė prašė nekaltinti saviškių prieš kitų partijųžmones: „Patiems nesèti nusiminimąžmonėse ir visuomenèje, o reikia stiprinti viltimi geresnès ateities. Nèra to blogo, kas neišeitu geran, jeigu tik viską tinkamai panaudosime, jeigu tarpe bus vienybès, susitarimo... [...] Blogai daro tie draugai, kurie s-gai sunkių laikų sulaukus, meta viską, nukrato nuo darbo rankas ir bėga pas kitus, kad nenustotų vietų arba kai kitaip nenukentètų. Tokių draugų mes nesigailèkime. Sakoma yra - pažinsi draugą patekęs nelaimèn" ${ }^{\text {"25 }}$. Atsišaukimo pabaigoje LVLS CK pakvietė partijos narius dirbti: „Dabar mes vèl turime pradèti ramios kovos darbą (paryškinta autoriaus). $\mathrm{Ne}$ turime užmiršti būsiančių rinkimų i savivaldybes ir gal į kitą Seimą “26. Iš atsišaukimo matyti, kad liaudininkų vadovybè, nepaisydama visiškos kapituliacijos perversmo metu, tikejjosi gerokai pavèluotais savo aplinkraščiais nuraminti partijos narius ir toliau valdyti partiją. Kita vertus, iš kitų šaltinių matyti, kad liaudininkų vadai dar nebuvo praradę vilties ir tikejosi būti pakviesti bendrai valdyti šalị su kitomis partijomis. Tų pačių metų sausio $26 \mathrm{~d}$. „Lietuvos žinių“ vedamajame straipsnyje „Užburtas ratas“ LVLS išreiškè viltị, kad didžiosios partijos susitars tarpusavyje ir bus sudaryta parlamentinè valdžia ${ }^{27}$. Vis dèlto valdžioje įsitvirtinę tautininkai net neketino su kitomis partijomis dalytis valdžia.

${ }^{23}$ LVLS CK sekretoriato atsišaukimas $1927 \mathrm{~m}$. gruodžio 17 d. perversmo proga. Lietuvos valstiečiu liaudininkų s-gos kuopos valdybai. Draugai! Lietuvos mokslu akademijos bibliotekos Rankraščiu skyrius (toliau - LMAB RS). F. 192-138.

${ }^{24}$ Ten pat.

${ }^{25}$ Ten pat.

${ }^{26}$ Ten pat.

${ }^{27}$ Užburtas ratas (vedamasis). Lietuvos žinios. 1927, sausio 26, p. 1. Šiame straipsnyje buvo paneigti gandai, kad valstiečiai liaudininkai gali dalyvauti valstybės valdyme: „Spaudoje ir visuomenejje dabar kalbama apie èjimą valdžion valst. liaudininkų. Tačiau, kiek mums teko patirti iš val. liaud. C. K. pirmininko prof. Lašo, jokių formalių derybų valdančios grupès su val. liaud. šiuo reikalu ligi šiol nèra net pradejjusios. Todẻl ir visa atsakomybė prieš tautą už galimas sunkias neparlamentinio valdymo pasėkas turi tekti ik toms grupėms, kurios gruodžio $17 \mathrm{~d}$. įvykius siekia išnaudoti savo partijų tikslams“". LVLS liko opozicine partija ir pasisakẻ už parlamentarizmo atgaivinimą ir vis labiau ėmé kritikuoti parlamentarizmą smerkiančius tautininkus. Viename iš straipsnių 1927 m. kovo 19 d. jie teigè, kad tautininkai rašo „kas dieną apie parlamentarizmo krizị“ (Ar nenusibos? (vedamasis). Lietuvos žinios. 1927, kovo 19, p. 1). 
Iš pagrindų pakitusi ir pasunkẻjusi valstiečių liaudininkų padètis netenkino aktyvesnių partijos narių. Nuo trečiojo dešimtmečio pabaigos pačioje partijoje vis daugiau atsirado skeptikų ir partijos vadovybės kritikų, kurie savo pažiūras atvirai èmè dėstyti Centro komitetui. Valdžios suvaržyta partijos veikla, skyrių sumažèjimas, neplètojama veikla pirmiausia papiktino Telšių valstiečių liaudininkų skyrių su Aleksandru Tornau ir Mečislovu Gedvilu priešakyje. Šio skyriaus vadovybe Felicijai Bortkevičienei laiške (apie 1928-1930 m.) atvirai išreiškè nepasitenkinimą partijos vadovų veikla. Žemaičiai piktinosi, jog ne tik nieko nedaroma, kad prieš valdžioje esančius tautininkus būtų imtasi bendrų opozicinių partijų veiksmų, bet ir partijos vadovybè rodo visišką neveiklumą: „Prie to neveiklumo, kuri per 2 metus rodè mūsų c. k., ar tokia ar kitokia jo orientacija neturi didelios reikšmès. Nei visuomenè, nei mes, nebemokame rimtai beįvertinti c. k. veikimą. C. k. atrodo mirusiu. Valst. liaud. ir visų rinkejju pasitikèjimas nuejjo niekais. Bet ir kiti vadai, kaip mūsų gerb. Dr. Grinius, Bortkevičienė, Sleževičius kodèl tai tyli. Plačioji visuomené nèra gavusi nè vieno pasiaiškinimo ar pranešimo laišką savo gerbiamo prezidento. Visuomenè nebežino, ar buv. Ministrių Pirmininkas pritaria dabartinei tvarkai - ar smerkia. Ar p. Bortkevičienè mano, kad dabartinei tvarkai atsiekti verta buvo visą amžių kovoti ir aukoti kas žmogui brangiausia? Taipogi ir kiti liaudininkų vadai kodèl tai tyli? Mumyse kilsta mintis ar liaudies vadai nebus tik fikcija, kuri drūtam žvalgybininkui šūktelèjus, išnyko kaip migla“"28. Laiško autoriai klausė, ar ,vadai pritaria Gen. Sekr. užimtai pozicijai, apsivyniojus toga majestotingai mirti - ar vis dèlto mano, kad būti vadu deda jiems tam tikrų atsakomingų pareigų. Mes jau seniai laukiame iš jų akcijos ir įsakymų “29. Laiškas atskleidè nepavydètiną LVLS būklę ir jos vadovybės pasyvumą po perversmo. Sudètingos padèties neslèpe ir partijos vadovybè. $1930 \mathrm{~m}$. CK rašte LVLS kuopoms ir veikejjams ji savo neveiklumą grindẻ lèšų trūkumu ir pačius provincijos skyrius skatino aktyviau veikti, prašè kartą per mènesi pranešti, kas kiekvienos kuopos ir atskiru asmenu bus padaryta, taip pat ragino mokèti partijos nario mokestit $^{30}$. Nepaisant CK méginimų suaktyvinti partijos veiklą, to padaryti nepavyko. Vietoj ramybès ir stabilumo ketvirtajame dešimtmetyje LVLS užgriuvo naujas išbandymų metas. Vienu metu reikejjo atlaikyti sunkius autoritarinès Lietuvos valdžios suvaržymus ir tuo pačiu metu ,gesinti“ isiplieskusius tarpusavio ginčus ir konfliktus. Nuolatiniai nesutarimai ir žymių partijų vadų, kaip Vinco Kvieskos

${ }^{28}$ Lietuvos valstiečių liaudininku Telšių apygardos komiteto laiškas Felicijai Bortkevičienei (apie 1928-1930 m.). LMAB RS F. 192-83, lap. 1-2.

29 Ten pat.

${ }^{30}$ LVLS CK. Lietuvos valstiečiu liaudininkų sajungos kuopoms ir veikejjams $1930 \mathrm{~m}$. balandžio $2 \mathrm{~d}$. LMAB RS. F. 192-139, lap. 4. 
ir jo šalininkų, vadinamujų,,kvieskininku‘“31, pašalinimas pareikalavo daug jègu iš senosios partijos vadovybès, ramybės nedavẻ ketvirtajame dešimtmetyje prasidèję nesutarimai su jaunaja LVLS karta, jos dažni priekaištai liaudininkų lyderiams, tarp jų - ir dèl visiškos kapituliacijos gruodžio 17-ają.

\section{Jaunosios valstiečių liaudininkų kartos nusivylimas senaisiais partijos vadais ketvirtajame dešimtmetyje}

Beveik visą ketvirtajį dešimtmetį vykęs „,kartų konfliktas“ valstiečių liaudininkų vadovybei buvo kur kas pavojingesnis nei jau minėti nesutarimai su ,kvieskininkais“. Jaunoji karta ėmė reikšti vis daugiau pretenziju dèl partijos neveiklumo, kritikuoti jos ideologiją. Jie niekaip negalèjo suprasti, kodèl 1926 m. gruodžio 17 d. valstiečių liaudininkų vadai liko pasyvūs. Bene geriausiai kritiką vadams i akis išrèžè liaudininku jaunosios kartos atstovas Marijonas Gregorauskas. 1934 m. sausio 15 d. LVLS Kauno skyriaus narių susirinkime jis reikalavo iš LVLS vadovų aktyvumo ir drąsos: „Demokratija nemoka būti drąsi ir patvari. Mes irgi tokių lepšių Lietuvoj esam turèję. Kada įvyko valstybès perversmas ministerius suèmè ir jie, pabūgę kad jų nesušaudytu, nuo visko atsisakè. Tokiems demokratams esant darosi sunku dèl mūsų Lietuvos. [...] Reikia demokratinèj visuomenèj dvasioj išauklèti visuomenę, kuri sugebėtų demokratiją tinkamai apginti. Jeigu 1926 m. vienas karininkas atvykęs išvaikẻ Seimą, tai irgi juk juokinga. Juk jie galèjo gintis. Reikia pasišventimo, kovos, bet ne lepšiškumo. Nuo $1926 \mathrm{~m}$. ivvykio mes demokratai ne tiktai nestiprejjam, bet visiškai smulkèjam ir silpnèjam. [...] Demokratai per daug isigijo ydų ${ }^{\text {‘32 }}$. Valstybès saugumo departamento mènesinëje apžvalgoje konstatuota, kad ,partijos veikimas išsiblaškęs, o jaunimas nori reformų ir aiškios linijos ${ }^{\text {‘333 }}$.

Dèl tokios kalbos M. Gregorauskas gavo îspejjimą iš valstiečių liaudininkų vadovybès ir turèjo pasiaiškinti dèl savo poelgio. Tačiau savo žodžių ne tik neatsièmè, bet

31 V. Kvieska dèl LVLS taktikos aktyviai pradejo reikštis 1932-1933 m. ir partijos CK atvirai èmè nesutarti su partijos pirmininku M. Sleževičiumi. Beveik dvejus metus savo planus spaudoje ir CK teike buvęs III Seimo narys ir vienas iš partijos lyderių Vincas Kvieska, kuris siūlè valstiečiams liaudininkams pasukti į dešinę ir suartėti su valdžioje buvusiais tautininkais. $1933 \mathrm{~m}$. gegužès 24 d. LVLS CK V. Kvieską pašalino iš partijos (posėdyje dalyvavo M. Sleževičius, F. Bortkevičienė, V. Oškinis, J. Geniušas, J. Akelaitis, Pr. Gluodas, C. Petrauskas, K. Ralys, K. Šaltenis, V. Cibulskis). Pašalinimo argumentas: „V. Kvieska savo pažiūromis (pareikštomis įvairioje spaudoje, kaip „Dienos Naujienos“ 236, ,Vagoj“ ir kt.) prieštarauja liaudininkų pagrindiniam nusistatymui“ (1933 m. gegužès 24 d. LVLS CK posėdis. LMAB RS. F. 192-57, lap. 40).

32 Valdininko raportas Valstybès saugumo policijos Kauno apygardos viršininkui $1934 \mathrm{~m}$. sausio $17 \mathrm{~d}$. LCVA. F. 378, ap. 3, b. 3474, lap. 32.

${ }^{33}$ Valstybès saugumo policijos Kauno apygardos 1934 m. vasario mèn. apžvalga. LCVA. F. 378, ap. 3, b. 3474 , lap. $144-145$. 
ir dar kartą priminè liaudininkų vadovybei. Be to, vasario $6 \mathrm{~d}$. LVLS CK iteiktame pareiškime liaudininkų vadovybei jis pamėgino analizuoti ketvirtajame dešimtmetyje atsiradusias bendras priežastis, dèl kurių daugelyje Europos valstybiųžlugo demokratinès santvarkos, prasidèjo vadinamoji demokratijos krizè. M. Gregorauskas kaltino demokratijos vadus nutolimu nuo liaudies, suburžuazèjimu ir sumiesčionèjimu, nekovojimu už savo idealus: „Gi sprendžiamuosiuose momentuose (jie - autoriaus pastaba) pasirodè esą silpnavaliai ir bailiai, nelinkę nė kiek pasiaukoti“‘34 . Jo teigimu, „kur demokratija turejo ir teturi taurius ir drąsius vadus, kur neisiveisè materializmas, ten ji atsilaikè nesigriebdama ypatingų priemonių, veikdama grynai normalių istatymu ribose, ten pati visuomene apgynè ją ir moraliai palaikè/pav. Suomija, Airija, Švedija, Norvegija, Čekoslovakija/‘35. M. Gregorauskas iš demokratijos vadų ir jos šalininkų reikalavo atkaklios kovos, pasiaukojimo, nebijoti kalëjimų ir net mirties ${ }^{36}$.

Valstiečiu liaudininkų vadovybei išdèstytos $\mathrm{M}$. Gregorausko nuostatos jam pačiam ir jaunajai kartai buvo kredo, kuri jie laikè savo idealu. Nesvarbu, kokiomis priemonėmis, svarbu tikslas, šiuo atveju - demokratijos santvarkos gynimas. To paties reikalavo ir iš senujų valstiečių liaudininkų vadų. Pateiktoje kalboje, nepaisant liaudininkų vadų praeities klaidu̧ tarp jų - Lietuvos demokratijos žlugimo, dar buvo reiškiama viltis, kad nuolatinè kova, ryžtingumas gali sugrąžinti masių ir partiečių pasitikèjimą. Liaudininkų vadams išsakyta kritika turèjo pagrindo, ypač - dèl valstiečių liaudininkų vadų neryžtingumo $1926 \mathrm{~m}$. gruodžio 17 d., tai savo atsiminimuose pripažino ir Prezidentas K. Grinius ${ }^{37}$.

Ketvirtojo dešimtmečio viduryje iškilusi jaunoji liaudininkų karta vis aktyviau kẻlè politinius tikslus. $1934 \mathrm{~m}$. nuo LVLS visiškai priklausoma Lietuvos jaunimo sajunga (toliau - LJS) (trumpiau - jaunimiečiai), tiksliau jos vadovybè, savo spaudoje atvirai pradëjo diskutuoti dèl tolimesnio organizacijos pobūdžio: likti kultūrine ar tapti politine jaunujų valstiečių liaudininkų organizacija. Iki tol didelè dalis jaunimiečių, būdami kultūrinès LJS nariais, praktiškai kartu priklause LVLS, užsièmė politika. Todèl viena grupė dabar siūlè daugiau nesislapstyti ir sajungą paversti politine organizacija.

${ }^{34}$ Kauno kuopos nario Marijono Gregorausko pareiškimas LVLS CK 1934 m. vasario 6 d. LMAB RS. F. 199-426, lap. 7-13.

35 Ten pat.

${ }^{36}$ Ten pat, lap. 9.

${ }^{37}$ K. Grinius, vertindamas LVLS ir LSDP valdymą $1926 \mathrm{~m}$. antroje pusėje, pripažino, kad kairiujų Vyriausybė nieko nedarè, kad ruošiamam 1926 m. gruodžio 17 d. perversmui užbėgtų už akių: „Gandų, kad kariuomenė ruošiasi perversmui, netrūko. Jie plito Kaune ir provincijoje. (...) Reikia apkaltinti valstiečių liaudininkų ir socialdemokratų vyriausybę, kuri buvo neryžtinga ir nesiẻmė priemonių laiku užgniaužti sąmokslą (paryškinta autoriaus). Bet ką gi, valdžioje buvo demokratinio nusistatymo žmonès, kurie buvo tikri, jog tautininkai, neturẻdami jokio užnugario visuomenėje, nesiryš brautis su ginklu rankoje valdžion. (...) Kitais žodžiais tariant, vyriausybẻ i tautininkų ir karininkijos sąmokslą pažiūrẻjo kaip i nerimtą žaidimą, ir šis politinių varžovų nepažinimas buvo tiesioginẻ tautininkų, krikščionių demokratų ir karininkijos padaryto perversmo pasisekimo priežastis“" (Eidintas, A. Kazys Grinius. Vilnius, 1993, p. 174-175). 
Šiuo klausimu pasiūlyta parengti naują sajungos pagrindų projektą. Kita jaunimiečių grupe buvo kategoriškai prieš tokias permainas. $1934 \mathrm{~m}$. kovo $22 \mathrm{~d}$. Julius Būtènas straipsnyje „Ar verta jaunimiečiams politikèti“ rašè, kad jau kuri laiką LJS Centro valdyba aktyviai dirba prie naujų sajungos įstatu ir pagrindų. Autoriaus teigimu, „,̌iaip jau jaunimiečiai nėra giliau susipažinę su tuo projektu, bet kiekvienam krinta i akis, kad, priẻmus tuos naujus įstatus, jaunimiečiai nesivadins vien jaunimiečiais, bet dar ir jaunaisiais liaudininkais ${ }^{\text {“38 }}$. Vadinasi, priẻmus naujus ịstatus, jaunimiečiai nebebūtų vien tik pažangaus jaunimo lavinimo ir švietimo organizacija, o taptų partija. LJS gyvavo jau dešimtmetį ir jos skyriai nebuvo nusiskundę dèl sajungos ịstatuc nereikalavo, kad sajunga būtų paversta partija. 1929 m. suvažiavime tik vienas asmuo (,tas pats, kuris ir dabar tai daro centre būdamas“ (pavardè nenurodyta - autoriaus pastaba) reikalavo, kad jaunimiečiai taptų valstiečiais liaudininkais. Tam griežtai pasipriešino K. Grinius, teigdamas, kad jaunimas suaugęs ir subrendęs pats pasirinkti sau tinkamą partija, o, „LJS svarbiausias dalykas - lavintis, šviestis, pažinti nešališkai ivairias visuomenines ir politines sroves, kad paskui, laikui atejus, galètų pasirinkti, kuri jo nusistatymams ir socialinei būčiai artimiausia“"39. J. Būtènas klausè, „tad iš kur atsirado tas reikalas supolitinti sajungą?“40 Jis siūlè išlikti nepartine organizacija, naujovèmis papildyti senuosius sajungos istatus, o naujų nepriimti. Iš to galima spręsti, kad J. Būtėnas buvo prieš bet koki jaunimiečiu politikavimą ir norèjo, kad sajunga ir toliau išliktų tik kultūrine organizacija, o jos nariai politinę partiją kaip siūlè K. Grinius, galètų patys pasirinkti.

Tokia J. Būtèno pozicija buvo ne visiems priimtina ir tame pačiame, „Jaunimo“numeryje išspausdintas jam prieštaraujantis straipsnis. Jo autorius A. Tornau (prisidengęs slapyvardžiu ${ }^{41}$ ) pasisakè už radikalius pokyčius LJS, kuriuos lemia pats gyvenimas. Baigdamas A. Tornau ragino neapsiriboti tik kultūrine veikla, vadintis ,jaunaisiais liaudininkais“, pasišvęsti „,kovai už liaudies laisvę", eiti kartu „,su gyvenamu momentu“, nes kitaip gyvenimas nueis kitu keliu, o ,mes pasiliksime prie vieškelio, vieni tolumoje, besvarstydami svarbius kultūros klausimus" ${ }^{\text {“42 }}$. I ši , ,kultūrinio“ darbo kelią jau seniai daug kas stumia. Saugokimès tokių patarimų “43.

Nepaisant kritikos, laimėjo pirmoji grupe ir LJS pagal naują statuta, nors ofici-

${ }^{38}$ Būtènas, J. Ar verta jaunimiečiams politikèti. Jaunimas. 1934, Nr. 4, p. 2 (po straipsnio antrašte pažymėta, kad straipsnis yra diskusinis).

39 Ten pat.

${ }^{40}$ Ten pat.

${ }^{41}$ Kaip savo atsiminimuose nurodė J. Būtènas, A. Tornau jam oponuodamas įrodinèjo, kad jaunimiečiai esą valstiečiai liaudininkai, nes CV kaip tik sudaro valstiečių liaudininkų žmonės. Taip pat daugelyje skyrių dirba valstiečiai liaudininkai, tad kam dar dangstytis, kam slèptis? (Būtènas, J. Lietuvos žurnalistai. Vilnius, 1991).

42 A. T-.[Tornau A.] Kas gi pagaliau mes esame? (atsakymas J. Būtènui). Jaunimas. 1934, Nr. 4, p. 2-3.

${ }^{43}$ Ten pat. 
aliai ir pasivadino „Jaunujų valstiečių liaudininkų organizacija“, išliko kultūrinio pobūdžio. 1991 m. išleistuose atsiminimuose J. Būtènas išsamiau paaiškino, kodèl jis prieštaravęs, kad LJS taptu politine organizacija ir isijungtu i LVLS gretas. Jo teigimu, ,dèl valstiečiu liaudininku pastebejjau, jog ta partija anaiptol nepasižyméjusi tokiais veiksmais, kuriais jaunimq trauktu. Turejau galvoje ju kapituliacija per 1926 m. valstybès perversma ${ }^{644}$ (paryškinta autoriaus). Šie žodžiai gerai atspindèjo kritiškąjaunujų valstiečių liaudininkų požiūrị i vadovybę, jų veiksmus gruodžio $17 \mathrm{~d}$. perversmo metu. Liaudininkų vadai, kad ir kaip stengėsi, savo autoriteto partijoje taip ir nesugebèjo sustiprinti. Dèl šios priežasties J. Būtènas ir jo stovyklos šalininkai nenorejjo, kad jaunimiečiai taptu politine organizacija. Priklausydami šiai sajungai, jie nebūtinai turèjo įsilieti į valstiečiu liaudininkų gretas.

1936 m. pradžioje Lietuvos valdžia išleido įsakymą, kuriuo uždraudè opozicinių partijų veiklą. Ją oficialiai turèjo nutraukti LVLS ir LJS. Nepaisant to, jos ir toliau veikè, tęsèsi „seniu“ ir jaunosios kartos nesutarimai. Jaunimas, matydamas, kad jokių permainų Lietuvos politiniame gyvenime nevyksta, toliau valdo A. Smetona ir tautininkai, o kitos partijos nustumtos, jų veikla suvaržyta, dar labiau nusivylè valstiečių liaudininkų vadais. Pradèta kalbėti apie partijos ideologinę krizę. Atskiro dèmesio verta $1936 \mathrm{~m}$. vasario $16 \mathrm{~d}$. studentų varpininkų draugijoje skaityta Juozo Geniušo paskaita „Varpininkų ideologija kitų ideologijų tarpe“, kurios klausėsi ir F. Bortkevičienè, A. Tornau. J. Geniušas, lygindamas LVLS ir kitu Lietuvos partijų ideologijas teigè, kad varpininkų ideologija ,,neturinti pilnumo“. Joje esą daug kas neaišku: ,Mes sakome esq demokratai. Bet tas maža dar šiais laikais tesako. Jei žmogus sakosi esqs demokratu, tai dar nežinoma, kaip jis yra nusistatęs ir ka jis galvoja“445 (paryškinta autoriaus). Iš to galima suprasti, kad liaudininkų gretose (taip pat ir jaunosios kartos) pasireiškè krizè, imta viešai abejoti savo partijos ideologija, o ką jau bekalbèti apie liaudininkų vadus. J. Geniušo teigimu, ,varpininkų pirmtakai yra kilę iš valstiečių luomo. Taigi valstiečiai ir jų reikalai turi būti tuo pagrindu, ant kurio mes turetume atsistoti ir juo remtis. Be to, reikètų nusikratyti atgyvenusiu prietaru, kad varpininku ideologai yra dr. V. Kudirka, Višinskis, dr. Grinius, dr. Staugaitis... Dabar, kai tik pradedama kurti varpininku ideologija, tai tuoj prisimenamas Kudirka, Višinskis, Staugaitis, Grinius... Tačiau juose nerandame atsakymo į daugeli klausimų. Jie buvo ne ideologai, bet pavyzdžiai. Kudirka, Višinskis nė negalvojo kurti ideologijos. [...] Dèl savo nenuoširdumo mes esame nemažai nukentëję: pasikeitus vëjams, bent 50 proc. savo žmoniųmes netenkam todèl, kad nebuvo nuoširdumo ir atsidavimo tam valstiečių luomui, kurio interesus mes esame pasiryžę ginti‘‘46. Iš J. Geniušo paskaitos matyti,

44 Būtènas, J. Lietuvos žurnalistai. Vilnius, 1991, p. 68.

$451936 \mathrm{~m}$. vasario $17 \mathrm{~d}$. valdininko raportas Valstybès saugumo policijos Kauno apygardos viršininkui. LCVA. F. 378, ap. 3, b. 4632, lap. 185.

46 Ten pat, lap. 186-187. 
kad analogiškos abejonès, svarstymai liudijo apie jaunosios valstiečiu liaudininkų kartos pasimetimą, blaškymąsi, pačių liaudininkų partijos galios mažèjimą.

Jaunujų liaudininkų pasimetimas, neturèjimas galimybių veikti, pasireiškusi ideologinè krizè, netikèjimas senaisiais liaudininkų idealais atvedè juos į aklavietę. Atslinkus Lietuvos nepriklausomybės sutemoms 1938-1940 m. iškilo klausimas: kur ir su kuo toliau eiti? Toki jaunosios kartos pasimetimą gerai atspindejo A. Drobnio žodžiai, 1938 m. lapkričio 5 d. pasakyti M. Sleževičiui: „Dabar varpininkai ${ }^{47}$ esanti palaida masè. Vieni jaučia save socialistu, kiti komunistu, treti kažin kuo“48 (paryškinta autoriaus). Jaunieji valstiečiai liaudininkai pareiškè, kad reikalingos reformos, bet senieji neturëjo naujų idèjų ir turëjo tai pripažinti ${ }^{49}$. Ilgametis valstiečių liaudininkų pirmininkas M. Sleževičius negalèjo to suprasti ir išreiškè nusivylimą jaunaja karta. Jis siūlè varpininkams per daug apie reformas negalvoti, bet intelektualiai lavintis ir ramiai laukti šviesesnio rytojaus, o tas rytojus esąs aiškus ir netolimas - tai matąs iš vis didejjančios liaudininkų dienraščio „Lietuvos žinios“ prenumeratos $^{50}$ ir visokių reiškinių, kurių konkrečiai neįvardijo.

M. Sleževičiaus pasiūlyta taktika vargu ar galèjo tenkinti jaunają liaudininku karta, kuri sieke „eiti koja kojon“ su staigiai besikeičiančiais gyvenimo i̇vykiais. Po $1938 \mathrm{~m}$. kovo mẻnesi paskelbto Lenkijos ultimatumo Lietuvai šalyje nestigo i̇vykiu, kurių sūkuryje labai sunku buvo išlikti neutraliais. 1939 m. rudeni, prasidèjus Antrajam pasauliniam karui, iš pradžių Justas Paleckis, netrukus ir kiti jaunieji valstiečiai liaudininkai tarẻ savo žodị ir parodé, ko iš tikrujųjie nori ar tikisi, o senieji valstiečių liaudininkų vadai M. Sleževičius, K. Grinius ir F. Bortkevičienè per visą A. Smetonos autoritarinio valdymo laikotarpi išliko gana pasyvūs ir nuoseklūs dar XIX a. pabaigoje - XX a. pradžioje sukurtoms senosioms varpininkų tradicijoms. J. Paleckis 1939 m. spalį Kaune prie prezidentūros viešai išdèstè savo kritines pažiūras Lietuvos

${ }^{47}$ Šiuo terminu ịvardijama jaunoji valstiečių liaudininkų karta.

48 Agento „Gruodis“ agentūrinis pranešimas 1938 m. lapkričio 8 d. LCVA. F. 378, ap. 1, b. 96, lap. 330 a, b.

${ }^{49}$ Ten pat.

${ }^{50}$ Ten pat, lap. 330-331. 1938 m. gegužès 23 d. ịvyko akcinės bendrovès „Varpas“ akcininkų susirinkimas, kuriame dalyvavo 20 žmonių, tarp jų: K. Grinius, M. Sleževičius, dr. J. Staugaitis, F. Bortkevičienė, B. Paramskas, V. Oškinis, V. Ruzgas, prof. V. Lašas ir kiti. Bortkevičienė perskaitė valdybos pranešimą apie paskutinius finansinius bendrovès reikalus. Jos teigimu, iš leidžiamų bendrovès leidinių didžiausią pažangą padarė „Lietuvos žinios“. 1936 m. „Lietuvos žinios“ davė apie 10000 Lt pelno, o 1937aisiais - apie 60000 Lt. „Lietuvos ūkininkas“, 1936 m. „davęs deficitą“, praèjusiais metais jau davè 7000 Lt pelno. „Nežiūrint ị neramius gyvenamus laikus, ultimatumų skraidymą ir fašizmo siautèjimą, demokratinè spauda, ypač Lietuvos žinios, tuomet didèja ir duoda vis didesni pelną. Turime džiaugtis, kad mūsų skatikais sukurta bendrovė gražiai klesti ir duoda pelno. Apskritai $1937 \mathrm{~m}$. bendrovè davè 53 545, 36 litus pelno. Bendrovès valdybon buvo išrinkti F. Bortkevičienė ir prof. V. Lašas“ (1938 m. gegužès 24 d. valdininko Juozo Šabano raportas Valstybès saugumo departamento Kauno apygardos viršininkui. LCVA. F. 378, ap. 1, b. 96, lap. 270-271). 
valdžiai ir siūlè Lietuvoje sukurti „Lietuvos laisvą darbo respubliką“. Jaunieji liaudininkai žavejjosi tokiu savo lyderio poelgiu ir pritare skelbiamoms idejoms. Savo „Pro memoria“, ¿teiktoje senajai valstiečių liaudininkų vadovybei, jaunieji liaudininkai rašè: „Mes su pasigèrèjimu žiūrime į tuos asmenis, kurie atvirai, nebijodami nukentèti, išdrista valdantiesiems pasakyti tiesos žodi, ypatingai jei tas žodis sutinka su mūsų ideologiniu nusiteikimu. Tokį konkretų prieš valdančiuosius išstojimą mes laikome mūsų draugo Justo Paleckio pasakytą atvirą, drąsų žodị prezidentūros sodely. Jeigu detalèse Paleckio iškelti reikalavimai ir perredaguotini, tai vis tik, jie savo esmejje niekuo nenusideda liaudininkiškajai ideologijai ir jau jokiu būdu nèra komunizmo propagavimas ${ }^{\text {" } 51}$. Pacituoti žodžiai rodo, kad okupacijos išvakarėse liaudininkųpartijoje išryškejo didelè takoskyra tarp ,senių“ ir jaunosios kartos. Pastarieji, kritikuodami senają kartą, siekė aktyviai veikti, pasisakè už radikalias kairiąsias idejas ir turejo politinių ambicijų, sukūrẻ savo programą, kurią viešai išdėstė jų lyderis J. Paleckis. Tai ir buvo pagrindinė priežastis, nulèmusi jaunosios kartos iškilimą 1940 m. birželi, Sovietų Sajungai okupavus Lietuvą.

\section{Išvados}

1. Kai iškyla pavojus demokratinei santvarkai, ją reikia ginti, dèl jos aukotis, pareikšti bent simbolini protestą. Taip reikia elgtis dèl tautos, savo paties, partijos gerovès, vardan ateities. Liaudininkų vadovybès veiksmai 1926 m. gruodžio 17 d. - priešingas atvejis, kaip nereikia elgtis, kai iškyla grèsmė demokratinei santvarkai.

2. Valstiečiu liaudininkų vadų $1926 \mathrm{~m}$. gruodžio 17 d. besąlyginè kapituliacija ir neveiklumas vẻlesniu laikotarpiu turèjo skaudžiu padarinių tolimesnei partijos raidai. Ketvirtajame dešimtmetyje subrendusi jaunoji liaudininkų karta, siekdama aktyviau veikti, nepasitikėdama senaisiais partijos vadais ir abejojanti liaudininku partijos ideologija, taip pat neturèdama aiškios veikimo krypties bei veikiama sudètingų tarptautinių ir vidaus politinių sąlygu, atsidūre aklavieteje. Okupacijos išvakarèse jaunajai liaudininkų kartai neabejotinu kelrodžiu tapo ,sukairèjęs“" Justas Paleckis ir jo skelbiamos radikaliai kairiosios idejjos.

${ }^{51}$ Išsamiau žr.: Tamošaitis, M. Justas Paleckis ir jaunieji valstiečiai liaudininkai Lietuvai atgaunant Vilniaus kraštą (1939 m. ruduo). Vilniaus istorijos metraštis. Vilnius, 2006, t. 1. 


\title{
DEMOCRACY ,TREASON" IN DECEMBER 17, 1926 LESSONS TO THE LITHUANIAN PEASANT POPULIST UNION
}

\author{
Mindaugas TAMOŠAITIS
}

\section{Summary}

Keywords: Lithuanian Peasant Populist Union, Coup d'etat of December 17th, Democracy, ,generation conflict”, Young Peasant Populists, Lithuanian Youth Union.

Article covers events connected with takeover of December 17, 1926, after witch democratic state system collapsed and authoritarian regime was implemented in Lithuania. Coup d'etat betrayed democracy. Contemporary President Kazys Grinius and Prime Minister Mykolas Sleževičius, leaders of Peasant Populists also have to share responsibility for this event. Old and famous „Tollers” (,Varpininkai”) possessing state authority in their hands didn't do anything to protect democracy, the Parliament and the Government from the plotters. They remained unenterprising during the next several weeks after the takeover and in that way they had helped to "legalise" the plotters government. Even after such event they didn't bother to explain motives of such actions. Former coalition partners Social Democrats couldn't justify this.

Such tactics of the Peasant Populist leadership attained lot of critics from active society and even party members, in that way reducing, ,weight" and standing of the party leaders. This problem clearly showed up in the $4^{\text {th }}$ decade of the $20^{\text {th }}$ Century in a context of conflict between old and young generation Peasant Populists members. Youth tried to make party to act more actively. One of the main reasons of conflict was the party leaders' passiveness during the events of December 17, 1926. Young generation criticised older leaders and couldn't forgive them for the betray of democracy and party program. This conflict was felt during whole $4^{\text {th }}$ decade. These were the main reasons why young and old generations couldn't find modus vivendi and it was clearly seen on the eve of Lithuanian occupation by USSR.

Article concludes that the actions of the Lithuanian Peasant Populist party leadership during the coup d'etat of 1926, is revealing example of bad action in order to protect democracy. 